\title{
Tree Nut
}

National Cancer Institute

\section{Source}

National Cancer Institute. Tree Nut. NCI Thesaurus. Code C72067.

A dried fruit or fruit part that develops from a tree and is comprised of a hardened shell, which in true nuts is derived from the ovary wall of the plant, and an encapsulated, edible kernel or seed. 